\title{
Nasal mites of Tyrannidae (Aves) in Brazil
}

\author{
Mendes, MM. ${ }^{a *}$, Mascarenhas, CS. ${ }^{a}$, Sinkoc, AL. ${ }^{b}$ and Müller, G. ${ }^{a}$ \\ ${ }^{a}$ Laboratório de Parasitologia Animais Silvestres, Departamento de Microbiologia e Parasitologia - DEMP, \\ Instituto de Biologia - IB, Universidade Federal do Pelotas - UFPel, Campus Universitário Capão do Leão, \\ s/n, CEP 96010-900, Capão do Leão, RS, Brazil \\ bDepartamento de Clínica Médica Veterinária, Faculdade de Agronomia e Medicina Veterinária, \\ Universidade Federal do Mato Grosso - UFMT, Av. Fernando Corrêa, 2367, CEP 78060-900, Cuiabá, MT, Brazil \\ *e-mail: marianammendes@hotmail.com
}

Received July 16, 2012 - Accepted March 26, 2013 - Distributed May 31, 2014

\begin{abstract}
A total of 81 Tyraniidae birds were examined, 80 Pitangus sulphuratus (Linnaeus, 1766) (Great kiscadee), and one Machetornis rixosa (Vieilot, 1819) (Cattle tyrant), for collection of nasal mites, which were identified as Ptilonyssus spinosus (Brooks \& Strandtmann, 1960) and Sternostoma longisetosae (Hyland, 1961) (Rhinonyssidae). This finding characterises the first report of $P$. spinosus and S. longisetosae in P. sulphuratus, and the first record of $P$. spinosus in M. rixosa, and expands the geographic distribution of these species. It is the first occurrence of S. longisetosae in the Neotropics, and the first citation of P. spinosus in the state of Rio Grande do Sul, Brazil.
\end{abstract}

Keywords: Pitangus sulphuratus, Machetornis rixosa, Rhinonyssidae.

\section{Ácaros nasais de Tyrannidae (Aves) no Brasil}

\section{Resumo}

Foram examinadas 81 aves Tyraniidae, 80 Pitangus sulphuratus (Linnaeus, 1766) (Bem-te-vi) e um Machetornis rixosa (Vieilot, 1819) (Suiriri-cavaleiro) para coleta de ácaros nasais, os quais foram identificados como Ptilonyssus spinosus (Brooks \& Strandtmann, 1960) e Sternostoma longisetosae (Hyland, 1961) (Rhinonyssidae). Este achado caracteriza o primeiro relato de $P$. spinosus e $S$. longisetosae em $P$. sulphuratus e o primeiro registro de $P$. spinosus em $M$. rixosa, e amplia a distribuição geográfica destas espécies, sendo a primeira ocorrência de $S$. longisetosae na região neotropical e primeira citação de P. spinosus no Rio Grande do Sul, Brasil.

Palavras-chave: Pitangus sulphuratus, Machetornis rixosa, Rhinonyssidae.

\section{Introduction}

Pitangus sulphuratus (Linnaeus, 1766) (Great kiscadee) is endemic in the American continent. It is distributed from the United States (Texas) to Argentina, occurring throughout the Brazilian territory (Sick, 1997). Machetornis rixosa (Vieilot, 1819) (Cattle tyrant) occurs in Venezuela, Bolívia, Paraguay, Argentina, Uruguay, and in Brazil from the state of Maranhão to the state of Rio Grande do Sul (Mendes et al., 2000).

In Brazil, studies with nasal mites underwent great advances between the 1940s and 1970s, with works performed by De Castro (1948), Pereira and De Castro (1949), Amaral (1968) and Amaral and Rebouças (1974). They described new species of nasal mites parasitising several species of birds. In the state of Rio Grande do Sul, Paulsen (2006), Sinkoc (2006) and Mascarenhas et al. (2009) described the occurrence of Rhinonyssus rhinolethrum (Trouessart, 1895) in Netta peposaca (Vieillot, 1816); Dendrocygna viduata (Linnaeus, 1766) and Dendrocygna bicolor (Viellot, 1816); Callonetta leucophrys (Vieillot, 1816) and Cygnus melanocoryphus (Molina, 1782), respectively.
Coimbra (2007) reported the parasitism in Columbina picui (Temminck, 1813) by Mesonyssus sp., Avancini (2009) reported the parasitism by Rhinonyssus sp. in Vanellus chilensis (Molina, 1782), and Mascarenhas et al. (2011) reported Ptilonyssus sairae (Castro, 1948) and Sternostoma pirangae (Pence, 1976) in Paroaria coronata (Miller, 1776). In this context, this study aims to contribute to the knowledge of nasal mites of Brazilian birds.

\section{Material and Methods}

Tyrannidae birds, a total of 81 , being 80 Pitangus sulphuratus and one Machetornis rixosa, from these 59 P. sulphuratus were sent by the Núcleo de Reabilitação da Fauna Silvestres e Centro de Triagem de Animais Silvestres da Universidade Federal de Pelotas (NURFS-CETAS/ UFPEL), where the birds died; the others were found dead from having been run over. The birds were from the municipality of Pelotas and neighbouring municipalities which are located between the geographic coordinates 
$31^{\circ} 00^{\prime} 58.44^{\prime \prime} \mathrm{S}, 52^{\circ} 03^{\prime} 13.34^{\prime \prime} \mathrm{W}$ and $33^{\circ} 32^{\prime} 06.45^{\prime \prime} \mathrm{S}$, $53^{\circ} 21^{\prime} 08.98^{\prime \prime} \mathrm{W}$.

The collection of nasal mites was performed by adaptation of the technique of Fain (1957), cited by Amaral and Rebouças (1974), the specimens were cleared with lactophenol, mounted between slide and coverslip in Hoyer's medium and examined under an optical microscope. Identification was performed according to Systematic Keys of Pence (1975) and Knee and Proctor (2010), and the original species descriptions made by Brooks and Strandtmann (1960) and Hyland (1961). Parameters of prevalence, mean abundance and mean intensity were estimated according to Bush et al. (1997), as well as the sex ratio between males and females.

\section{Results}

The nasal mites were listed in the arthropod collection of the Laboratory of Wild Animals Parasitology, Department of Microbiology and Parasitology, Biology Institute, Federal University of Pelotas, with the numbering from 417 to 443 .

Of the 80 P. sulphuratus examined, ten were parasitised by Ptilonyssus spinosus (Brooks \& Strandtmann, 1960), four by Sternostoma longisetosae (Hyland, 1961). Ptilonyssus spinosus has showed a prevalence of $12.5 \%$, mean abundance of 1.1 , mean intensity of 8.8 , and sex ratio a male for 4.17 females. S. longisetosae has showed prevalence of $5 \%$, mean abundance of 0.12 , and mean intensity of 2.5. All specimens collected were females.

Machetornis rixosa showed parasitism by two female of P. spinosus.

\section{Discussion}

This mite Ptilonyssus spinosus has been reported parasitising Tyrannidae birds in Cuba and in North America (Černý and Dusbábek, 1970, Pence 1975), and in Brazil, Amaral (1963) reported this species parasitising Tyrannus melancholicus melancholicus (Vieillot, 1819) in the state of Paraná.

Knee and Proctor (2010) listed the occurrence of S. longisetosae in North American (Canada) tyrannids.

In the one bird, $P$. sulphuratus, there was a parasitic association between the two species, S. longisetosae and $P$. spinosus. Parasitic association between nasal mites is rarely cited. Pence (1973) reported the finding of multiple species in one host, but he neither indicated which species of mites were involved nor the hosts.

Spicer (1987), in Mexico, has examined 103 birds from several families: four specimens belonged to Tyrannidae, and only one individual of the genus Empidonax (Cabanis, 1855) showed parasitic association between the mites Ptilonyssus tyrannus (Brooks and Strandtmann, 1960) and Sternostoma pencei (Spicer, 1984), concluding that parasitic association occurs sporadically.

Pitangus sulphuratus is a new host for the mites P. spinosus and S. longisetosae, as well as M. rixosa appear as a new host for the nasal mite $P$. spinosus. This report extends the geographic distribution of these species, being the first occurrence of S. longestosae in the Neotropics, and the first citation of P. spinosus in the state of Rio Grande do Sul. This is also the first report of parasitic association between P. spinosus and S. longisetosae.

Aknowledgements - We thank the Núcleo de Reabilitação da Fauna Silvestres e Centro de Triagem de Animais Silvestres da Universidade Federal de Pelotas for donating the animals, and CAPES and CNPq for financial support.

\section{References}

AMARAL, V., 1963. Notas sobre ácaros nasais com a descrição de uma nova espécie (Acarina: Rhinonyssidae Vitz, 1935). Arquivos do Instituto Biologico, vol. 30, p. 103-108.

AMARAL, V., 1968. Notas sobre ácaros nasais com a descrição de duas novas espécies: Ptilonyssus zeferinoi n. sp. e Sternostoma clementei n. sp. (Acarina: Rhinonyssidae). Lista das espécies descritas no Brasil e seus hospedeiros. Arquivos do Instituto Biologico, vol. 35, p. 107-126.

AMARAL, V. and REBOUÇAS, MM.,1974. Notas sobre ácaros rinonissídeos de aves brasileiras (Mesostigmata - Rhinonyssidae). O Biológico, vol. XL, p. 52-56.

AVANCINI, LF.,2009. Helmintos e artrópodes de Vanellus chilensis (Molina, 1782), quero-quero, da região sul do Rio Grande do Sul. 58 p. Pelotas: Universidade Federal de Pelotas. Dissertação de Mestrado em Parasitologia.

BROOKS, DL. and STRANDTMANN, RW., 1960. The Nasal Mites (Acarina) of Some West Texas Flycatchers (Tyrannidae). Journal of Parasitology, vol. 46, p. 418-432. PMid: 13804776. http://dx.doi.org/10.2307/3275132.

BUSH, AO., LAFFERTY, KD., LOTZ, JM. and SHOSTAK, AW., 1997. Parasitology meets ecology on its own terms: Margolis et al. Revisited. Journal of Parasitology, vol. 83, no. 4, p. 575-583.

CASTRO, MP., 1948. Reestruturação genérica de família Rhinonyssidae Vitzthum, 1935 (Acari: Mesostigmata: Gamasides) e descrição de algumas espécies novas. Arquivos do Instituto Biologico, vol. 18, p. 253-284.

ČERNÝ, V. and DUSBÁBEK, F., 1970. The nasal mites of Cuban birds. II. Ptilonyssidae and Rhinonyssidae (Acarina, Mesostigmata). Acarologia, vol. 12, no. 3, p. 479-491.

COIMBRA, MAA.,2007. Artrópodes e nematóides parasitos de Columbina picui (Temminck, 1813) (Aves: Columbidae) nos municípios de Pelotas e Capão do Leão, RS, Brasil. Pelotas: Universidade Federal de Pelotas. 62 p. Dissertação de Mestrado em Parasitologia.

FAIN, A.,1957. Les acarines dês familles Epidermoptidae et Rhinonyssidae parasites dês fosses nasales D'oiseaux au Ruanda - Urundi et au Congo Belge. Annales du Musee Royal du Congo Belge, Tervuren, Sc. Zool. vol. 60, p.1-176.

HYLAND, KE., 1961. Sternostoma longisetosa, a new species of nasal mite from the eastern kingbird with notes on the occurrence of Tyranninyssus spinosus Brooks and Strandtmann in southern Michigan (Acarina: Rhinonyssidae). Acarologia, vol. 3, p. 279-284.

KNEE, W. and PROCTOR, H., 2010. Interactive HTML-based Dichotomous Key to Female Rhinonyssidae (Mesostigmata) from Birds in Canada. Canadian Journal of Arthropod Identification, no. 9. 
MASCARENHAS, CS., BRUM, JG., COIMBRA, MAA. and SINKOC, AL., 2009. Novos Hospedeiros para o Ácaro Nasal Rhinonyssus rhinolethrum (Trouessart) (Gamasida: Rhinonyssidae) no Brasil. Neotropical Entomology, vol. 38, no. 5, p. 695-696. PMid:19943024. http://dx.doi.org/10.1590/ S1519-566X2009000500024

MASCARENHAS, CS., COIMBRA, MAA., MÜLLER, G. and BRUM, JGW., 2011. Nasal Mites (Gamasida: Rhinonyssidae) of Paroaria coronata (Miller) (Passeriformes: Emberezidae). Neotropical Entomology, vol. 40, no. 4, p. 507-508. PMid: 21952970. http://dx.doi.org/10.1590/S1519-566X2011000400016.

MENDES, ILV., MONDIN, CA. and STREHL, T.,2000. Guia ilustrado de fauna e flora para o Parque Copesul de Proteção Ambiental. Porto Alegre: COPESUL/FZB. 209 p.

PAULSEN, RMM.,2006. Caracterização de helmintos e artrópodes parasitos de Netta peposaca (Vieillot, 1816) (Marrecão-dapatagônia) (Aves:Anatidae) no Rio Grande do Sul. Rio Grande do Sul: Universidade Federal do Rio Grande do Sul. 100 p. Dissertação de Doutorado em Ciências Ciências Veterinárias.

PENCE, DB., 1973. The nasal mites of birds from Louisiana: IX Sinopsis. The Journal of Parasitology, vol. 59, no. 5, p. 881-892. http://dx.doi.org/10.2307/3278429.
PENCE, DB.,1975. Keys, species and host list, and bibliography for nasal mites of North american birds (Acarina: Rhinonyssinae, Turbinoptinae, Speleognathinae, and Cytiditidae). Texas: Texas Tech University Press. 148 p. Special Publications, no. 8.

PEREIRA, C. and DE CASTRO, MP., 1949. Revisão da subfamília Ptilonyssinae Castro, 1948 (Acari: Mesostigmata: Rhinonyssidae) com a descrição de algumas espécies novas. Arquivos do Instituto Biologico, vol. 19, p. 218-235.

SICK, H.,1997. Ornitologia brasileira. Rio de Janeiro: Nova Fronteira.

SINKOC, AL.,2006. Helmintos e artrópodes parasitos de marreca-piadeira (Dendrocygna viduata) (Linnaeus, 1766) $e$ marreca-caneleira (Dendrocygna bicolor) (Viellot, 1816) na região sul do Rio Grande do Sul. Rio Grande do Sul: Universidade Federal do Rio Grande do Sul. 110 p. Dissertação de Doutorado em Ciências Veterinárias.

SPICER, GS., 1987. Prevalence and host-parasite list of some nasal mites from birds (Acarina, Rhinonyssidae, Speleognathidae). Journal of Parasitology, vol. 73, no. 2, p. 259-264. PMid: 3585621. http://dx.doi.org/10.2307/3282076. 